\title{
Obituaries
}

Obituaries should be submitted by email to Kate Maynard at k.maynard@nature.com.

All submitted obituaries should be 350 words maximum in length (apart from obituaries for past presidents of the BDA where the length should be $700-800$ words).

Content of the obituary is down to the individual author, and the approval of the family should be given for the obituary prior

to submission to the $B D J$.

\section{GLEN BUXEY-SOFTLEY}

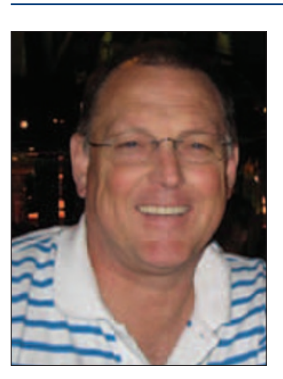

Glen Buxey-Softley qualified with a BDS from the University of Bristol in 1976, subsequently working in Stubbington and Portsmouth before joining Ken Coward in his Polygon practice in 1979. He stayed there until 2001 when he opened the St Francis practice with his friend and colleague Colin Goh.

In his very early days as a dentist Glen helped pilot an experimental vocational training scheme for newly qualified dentists. This scheme, now known as Dental Foundation Training, thrives today and remains an essential finishing school for newly qualified dentists.

Between 1989 and 1998 Glen also held a part-time post as Clinical Assistant in restorative dentistry and oral surgery at Southampton General Hospital treating patients with complex medical and dental conditions.

Glen was a member of the British Dental Association, SAAD, the British Dental Health Foundation and Denplan Excel.

From 1982 Glen was a continuous and a very active member of the Local Dental Committees (LDCs). Without people like Glen, who are prepared to get involved, LDCs would not exist to support dentists and patients. Glen was the current LDC Treasurer for Hampshire and Isle of Wight LDC and his LDC colleagues are devastated by his loss and will miss his key contributions.

Glen was also a past Chairman of Southampton Oral Health Advisory Committee working with local health managers to support and improve dental services for patients in Southampton and also a member of the Department of Health Oral Health Pathway Committee setting standards for dental examinations and providing advice to the National Institute of Clinical Excellence.

Last August Glen became a trainer for the Dental Foundation Scheme for newly qualified dentists. Deanery trainers and trainees held a minute's silence in the Deanery on Thursday 19 May, a unique event that had not happened before, speaking volumes about how he influenced his colleagues.

Glen died suddenly and unexpectedly to the great shock of all who knew him on Monday 16 May. His funeral drew a remarkable attendance from all ages and walks of life, demonstrating the esteem he was held in by family, friends and colleagues.

M. Norton

\section{DAVID GEORGE WATT}

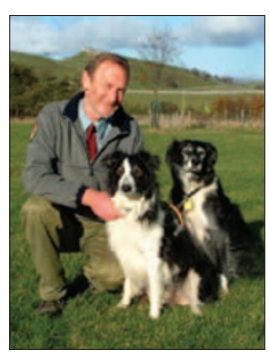

It is with sadness that I write upon the death of David George Watt (aged 63) who was killed in an air crash on 5 May 2011, at Kirkby Stephen. He was piloting

a plane he had built himself and flown for many years.

David was a man of many talents, proud of his Scottish ancestry and of his late father's flair for engineering and invention, which David inherited. Born in Aberdeen, from the age of 12 he was brought up in Weybridge. He graduated BDS from the Royal Dental Hospital, London in 1970. After House Officer posts he undertook a VSO year as SHO in Lagos, Nigeria. The following year he returned to England as a Community Dental Officer in Surrey where he met Anette.

In 1975 he acted as regional Dental Officer in NW Province in Zambia. Anette and David were married and their honeymoon was spent travelling by motorbike across Africa. David then worked in general practice in Inverness in 1976 and in Samsoe, Denmark for two years - Anette's native country.

David had the chance to buy a general practice in Kirkby Stephen, Cumbria and soon threw himself into many activities within the community, notably the mountain rescue team and Search \& Rescue Dogs Association.

Unfortunately David had a climbing accident and damaged his hand which forced him into early retirement from clinical work and in 2002 he sold his practice. The injury did little to slow him down. In 2005 he studied Forensic Medical Sciences and joined the Kenyon International register for disaster work. In 2009 he attended the Spanair air crash in Madrid and last year the Afriquyah air crash in Tripoli.

Judging by the turn-out at the overflowing church, David touched many people's lives in some way. He was proud of his son Andrew and daughter Alison and their achievements and in all of these things he was quietly yet ably supported by Anette. Although he died doing something he loved, the dental profession has lost an important cog, and Anette, Andrew and Alison their mainstay.

John K. Ashman 